\title{
UPLIFTING SPEAKING SKILL THROUGH COMMUNICATIVE APPROACH AT GRADE V OF PADURENAN II STATE ELEMENTARY SCHOOL IN BEKASI OF ACADEMIC YEAR 2016 / 2017
}

\section{Atie Hidayati}

Postgraduate Student of State University of Jakarta, Indonesia tie_28@yahoo.com

Jl. Rawamangun Muka, Rawamangun Pulogadung, Jakarta Timur Corresponding author

\section{Informasi artikel}

Article history

Recieved

$: 23 / 02 / 2018$

Revised

$26 / 03 / 2018$

Accepted

:06/04/2018

Kata kunci:

Berbicara

Pendekatan, komunikatif

\begin{abstract}
Keterampilan siswa kelas V SDN Padurenan II dalam berbicara masih rendah. Ini dibuktikan dengan skor rata-rata sebelum memberikan tindakan, yaitu $66,67 \%$ atau dapat diartikan belum lengkap. Guru masih menerapkan metode pengajaran klasik dan metode pengajaran yang hanya didasarkan pada buku pedoman saja. Hal ini menyebabkan siswa menjadi kurang termotivasi sehingga mereka belum dapat meningkatkan keterampilan mereka di speaker port.Tujuan dari penelitian ini adalah untuk mengkomunikasikan pendekatan keterampilan berbicara pada siswa Sekolah Dasar.

Penelitian ini dilaksanakan di Sekolah Dasar Negeri Padurenan II di Bekasi di mana subjek penelitian adalah 30 siswa kelas VA yang melibatkan II siswa lakilaki dan 19 siswa perempuan. Partisipan yang terlibat dalam penelitian ini adalah guru yang merupakan guru yang melekat pada kelas VA dan kolaborator adalah guru sebaya dari kelas VB. Instrumen yang digunakan dalam penelitian ini adalah lembar observasi. Pendekatan komunikatif pada siswa kelas $\mathrm{V}$ dengan tema satu "Objek di Lingkungan Tentang," sub-tema "Manusia dan Lingkungan". Sedangkan pada siklus I sebanyak I9 siswa (63,3\%) selesai, dan II siswa $(36,7 \%)$ belum tuntas. Setelah semua dua tema 'Peristiwa dalam Kehidupan', sub-tema "Jenis Peristiwa dalam Kehidupan", sebanyak 30 siswa (I00\%) telah selesai dengan nilai rata-rata 78,60.
\end{abstract}

\section{ABSTRACT}

Key word:

Speaking,

Approach,

Communicative.
Skill of fifth grade student of Padurenan II State Elementary School in speaking report is still low. This is evidenced by the average scores before giving the action, which is $66.67 \%$ not yetcompleted. The purpose of this research is to know how far communicative approach was able to give the correctinfluence of speaking skill on the Elementary School's student.

The the method of this research is the action research. This research was implemented at Padurenan II State Elementary School in Bekasi where in the subject of research was 30 students of class VA.. The Instrument that used in this research was observation sheet. Pursuant of processing result and analysing data, hence conclusion from this research result was significant improvement of speaking skill through communicative approach on student of class $\mathrm{V}$ with the theme one " Object in Environment of About," subtema " Human being and Environmental". While at cycle I as much 19 students (63,3\%) completed, and II studenst ( $36,7 \%)$ not yet completed. After all at cycle of II theme two ' Event in Life", subtema " Kinds of Event in Life", as much 30 students ( $100 \%$ ) have been completed with the average value 78,60 .

\section{Introduction}

Language represents the important of all components in human life. Human being would not be abble to continue and lengthen their life better and regular without existence of Ianguage. Learning 
Ianguage to be utilized in everyday life represents the essential requirement of human being, because with the Ianguage human being will be able to think better. Language can link the meaning or idea which submitted wish, Ianguage can be realized in the form of oral and or article. Ianguage is communication's tool to submit the information, student learn to communicate with the others through various means, one of among other things is speaking.

Indonesian language represents the Iesson which is obliged to start from elementary education to college with the aim in order student to own the ability of Ianguage and to be able to develop it personality and also apply the Indonesian language in everyday communications to be better and real correct.In the world of education, Indonesian langauge is used as a language of carrier at school activities in any various science area. This matter shows the Indonesian language plays an important part in course of education in Indonesia.In Curriculum of Elementary School, Indonesian language study covers 4 aspects wich are: listening, speaking, reading, and writing. At aspect of listening in elementary school there are activities for example: listening teacher's story, listening fable, listening drama, listening child poem, listening news, listening discussion and also listening interview.

Aspect of speaking at elementary school there are activities for example : introducing ownself, telling a story, orating, discoursing, giving response, discussion, interview, simple meeting and also drama. Aspect of reading at elementary school there are activities for example : reading of introduction, recognizing signs of sound, reading piercing, reading fluently, reading techniquely, reading inwardly, reading quickly, reading critically, reading to respect and also read to amend. Aspect of writing at elementary school there are activities for example: writing start, lettering to apart, writing straightening joint, writing paragraph, writing composition, writing letter, writing news, writing oration copy and also write report.

Along as epoch growth, curriculum's change has been conducted. The last change results the Curriculum 2013 orienting to student in developing attitude competence, knowledge and also skill inwroughtly through processing study of student, from teaching to learning. Curriculum 2013 is drawn up to reply the requirement education of 2Ist century utilizing to yield the productive, creative, inovatif and affective student. In Curriculum 2013 Indonesian language represents one of fundamental subject and function as education's draft subject even takes position as Ianguage of science's draft.

Indonesian language study aims to increase skill of having Ianguage and literature, improving ability think and have natural existence, and also ability to extend the knowledge. Otherwise, student is also instructed to sharpen its feeling. Student is not only expected to be able to comprehend the submitted information barely or directly, but also comprehend the submitted information indirectly. Student is not being clever only in have natural existence, but also own the efficiency in social interaction and can respect the difference, as good as in relation of individual and also in society life, that has background of various religion and culture.

One of Ianguage's skill is speaking. In this research focussed on speaking skill. Speaking is ability to say the articulatory sound or words to express, to expressing, or submitting mind, idea, and feeling. For Elementary School student, speaking skill to represent one of ability which must be owned by the student, because speaking skill has been owned by every person who very requiring in communications, both for one way in character and also reciprocal or both. With the speaking skill owned hence student is able to submit the message so that student is able to communicate with everyone, also with the teacher, with the coeval friend and society of generally.

Hereinafter speaking represents the skill of submiting the message through oral language. Speaking is one of the very important owned skill and mastered by student. But the reality in field namely in class of V Padurenan II State Elementary School is still experienced in the speaking skill Iesson. The constraints among student are learn to release the opinion and interview activity. 
The Description of student's speaking skill ability in class $\mathrm{V}$ at the moment is student finds difficulties to converse or nervous about, sentence likely jib, student less dare or fear and also cannot talk well. At the time of interview for example: student is not yet able to use the sentence structure correctly, spell and intonation which is still less precisely and inappropriate expression fill or submitted message. The Description of student's speaking skill ability in class $\mathrm{V}$ is happened because teacher gets focused to conduct the study activity competency which must be reached so that disregard the ability or domination speaking in course of learning student. Despitefully teacher is often burdened using the media, so that frequently teacher give instruction to the student to do the speaking activity just giving value and finished items without evaluating student activity.

Pursuant to problems above, teacher requires to apply the correct study approach to increase speaking skill at student of class V elementary school. One of approach which can be applied namely through communicative approach. Communicative approach represents the Ianguage study giving ability of skill Ianguage to supported by Ianguage knowledge. Communicative approach is taught to obtain the information required in everyday life in order to student comprehends the study more having a meaning of. this Communicative approach can give the freedom to student to phrase the opinion verbally and also string up words to be told to its friends by itself.Communicative approach is oriented at learn process to teach the Ianguage of pursuant to duty and the communicate function. Elementary principle a] communicative approach is: a) items have to be consisted of by the Ianguage as a means of communications, $b$ ) design items have to emphasize the learn process to teach non discussion fundamental, c) items have to support to student to communicate to the manner normally.

Strategy learn to teach in communicative approach relied on by the way of active student learning, that is student got mixed up by a learn process actively. Strategy of pursuant to communicative approach procedure namely shorten the presentation dialogued, presented dialogued oral training, question and answer presentation, observation and study, withdrawal the conclude, interactive activity, making of duty and execution evaluate. Therefore, throughcommunicative approach of student is expected can setle the speaking skill so that be able to uplift skill to speaking evaluated according to, accuracy, and fluency speaking. Through communicative approach learning also can evaluate the student insuffiency intensively and give the required guidance so that learn activity holds more active with interest and interactive.

In its relation with the above problems background and supported by a relevant research which have been conducted by a other researcher previously namely result of research " Uplifting Of Skill Converse through Method of Group Discussion at Student of class V SDN Sampaka" by Eresia Lamajau ( UNTAD 20I4) concluding through study of method of group discussion effectively experience of the improvement of activity of student and teacher and also result of learning complete by clasical and individual.

Research of about " Communicative Approach Applying To Increase Speaking Skill The Student of Class V SD Negeri II3 Pekanbaru" by Rahmatul Yusna ( University Riau 20I2) concluding communicative approach can improve the learn activity of teacher and student and also learn process becomes more active and motivated so that result of learning complete individually or clasical.

From former research result, one and second, can be seen that a communicative approach gives the result which can improve the activity learn and student learn and also result of learning complete by clasical and individual at speaking activity. Thereby pursuant to description and also fact in field, researcher means to perform a research in class V of about "Uplifting Of Speaking Skill through Communicative Approach at grade V SD Padurenan II in Bekasi of Academic Year 2016 / 2017". Through this research is expected knowable how far communicative approach is able to give the correct influence at peaking skill to the student of elementary school clasically. 


\section{Method}

The the method of this research is the action research. The Research has the character of partisipative in the meaning that researcher got engaged with a research, and has the character of the collaborative because it is entangling with other party (collaborator). Research is using the procedure of learning implementationthrough communicative approach at Indonesian Languange study. Research Procedure is using the research procedure model of Kemmis \& Mc Taggart that has nine phases, I) presentated shorten dialogued 2) presented oral training dialogued 3) question and answer presentation 4) analyst and study 5) withdrawal the conclude 6) interpresentation activity 7) oral product activity 8) duty gift, and 9) execution. The Subject of this research is student of class VA Elementary School of State of Padurenan II Kota Bekasi, West Java amount to 45 responders. Appliance to collect the accurate data is by using sheet of observation instrument. This sheet represents the instrument to note the accurate data as according to occurence at the time of study process take place. At this observation sheet contains about statement matching with research indicator.

This Research is using quantitative data. Technique of collecting data in this research is with the technique test and non test. Collecting data of test is using assessment sheet, talk with the target to assess the student attainment after conducted by research in course of study. Assessment to speak skill of the student is conducted by manual at instrument grille which have been made. This matter is conducted by researcher so that can see quantitatively make-up of skill result. While non test technique is conducted by I) direct observation using the sheet of observation of action watcher learn and student during study process. Observation is conducted since early study activity untill end its study activity 2) field note is to note each action conducted by teacher and student and entire event influencing action execution in class 3 ) documentation in the form of photos during study activity take place, and 4) documentation in the form of video during process of speaking skill activity.

\section{Results and Discussion}

The research findings in the field about learning speaking skills on students of grade VA Padurenan II State Elementary Schoolin Mustikajaya Bekasi through communicative approach. Researchers serve as planners, executors, and teachers in the classroom during classroom action research. The study was conducted for two cycles, each cycle consisting of two meetings. The time allocation for each meeting is 70 minutes $(2 \times 35$ minutes). Implementation of each cycle through several stages, namely planning (planning), the implementation of action (acting), observation (observing), and reflection (reflecting). The time allocation for each meeting is 70 minutes $(2 \times 35$ minutes). Implementation of each cycle through several stages, namely planning (planning), the implementation of action (acting), observation (observing), and reflection (reflecting).

Research is executed during two cycles, every cycle is consisted of twice meeting. Time allocation every meeting is 70 minute ( $2 \times 35$ minute).

\section{Pre-cycle}

The implementationof Pre-cycle in the series of this researchis to determine the condition of learning speaking skills before being given action. The researchers conducted a pre cycle on September I2, 2017 with a time allocation of $2 \times 35$ minutes. The lesson takes place on themeI, "Objects in the Neighborhood" subtheme I "The form of things and its Character", learning 4 with the indicators issuing opinions about the balance of nature.

The results of speaking skills can be seen in the table below: 
Tables I. Distribution of Speaking Skill Pre cycle.

\begin{tabular}{|c|c|c|c|}
\hline \multirow{2}{*}{$\begin{array}{c}\text { Interval } \\
\text { Score }\end{array}$} & \multicolumn{3}{|c|}{ Total of student } \\
\cline { 2 - 4 } & Frequency & $\begin{array}{c}\text { Relative } \\
(\%)\end{array}$ & Cumulative \\
\hline $\mathrm{I} 4-27$ & 4 & $\mathrm{I} 3.33$ & $\mathrm{I3.33}$ \\
\hline $28-40$ & 8 & 26.67 & 40.00 \\
\hline $4 \mathrm{I}-53$ & 5 & 16.67 & 56.67 \\
\hline $54-66$ & 4 & $\mathrm{I} 3.33$ & 70.00 \\
\hline $67-79$ & 3 & $\mathrm{I} 0$ & 80.00 \\
\hline $80-92$ & 3 & $\mathrm{I} 0$ & 90.00 \\
\hline $93-100$ & 3 & $\mathrm{I} 0$ & 100.00 \\
\hline Total & 30 & $\mathrm{I00}$ & \\
\hline
\end{tabular}

Pursuant to data of table 4I hence assess the speakingskill the student at Pre cycle, shows acquirement which is at most value 28-40 amounting to 8 students, then assess 4 I-53 amounting to 5 students, to assess I4-27 and 54-65 amounting to 4 students. The result indicates that speaking skill ofthe student is still low so that an action is required for the next step study of research. As for tables of result speaking skill the the following student in Pre cycle:

Tables 2. Complete result of Speaking Skill Pre cycle.

\begin{tabular}{|l|c|c|}
\hline \multicolumn{1}{|c|}{$\begin{array}{c}\text { SpeakingSkill } \\
\text { Results }\end{array}$} & Student & Percent \\
\hline Completed & 10 & $33,33 \%$ \\
\hline Not Completed & 20 & $66,67 \%$ \\
\hline Total & 30 & $100 \%$ \\
\hline
\end{tabular}

From data of tables above, knowable that result of test precycle indicates that the average value of student reaches 37,8. By KKM 70, hence from 30 completedstudents amount to I0 students and which not yet completed amount to 20 students. The visual overview of the pre-cycle results in the diagram below:

Figure I: Diagrammatic Circle Result Chart of Pre-cycle Speaking Skills

\section{Precision Speech Practice Complete Result}

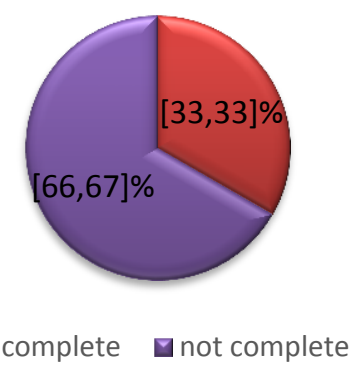


Based on the above explanation it can be concluded that the learning condition of speech skills is still low as follows: I). In the learning process the teacher does not pay attention to the activities of speech skills, when the students perform danya catch the beginning of speech only; 2). The teacher only uses the image media contained in the student's book; 3). Enthusiastic students in speaking lessons are still lacking because they still use lecture techniques; 4). There are no examples that students can see for example through the video to make it appear that the students are having difficulty speaking or being nervous, the sentence is not as clear as mumbling, the students are less brave or afraid and can not speak well. Therefore, it still needs the action on learning that can have a positive impact on the improvement of speech skills.

\section{Cycle I}

Based on the evaluation on the theme of "Objects in the Environment" on "People and the Environment", the results of speaking skills were obtained from the tests that were given at the end of cycle I in the form of tests presenting and presenting the results of interviews into the reports. This is done to see the extent to which the increase in speaking skills and pour it in the form of writing through a communicative approach. The following results presented data processing student learning outcomes in the table below:

Tables 3. Distribution of Speaking Skill cycle I

\begin{tabular}{|l|c|c|c|}
\hline \multirow{2}{*}{$\begin{array}{c}\text { Interval } \\
\text { Score }\end{array}$} & \multicolumn{3}{|c|}{ Total of student } \\
\cline { 2 - 4 } & Frequency & $\begin{array}{c}\text { Relative } \\
(\%)\end{array}$ & Cumulative \\
\hline $70-74$ & I & 36.67 & 36.67 \\
\hline $75-79$ & I0 & 33.33 & 70.00 \\
\hline $80-84$ & 2 & 6.67 & 76.67 \\
\hline $85-89$ & 0 & 0 & 76.67 \\
\hline $90-94$ & 6 & 20.00 & 96.67 \\
\hline $95-99$ & I & 3.33 & I00.00 \\
\hline Total & 30 & 100 & \\
\hline
\end{tabular}

Pursuant to data of tables above, speaking skill results to show the acquirement at most value 5460 that is as much II student with the percentage 36,67\%. Hereinafter description that complete student amount to 19 student ( $63,3 \%)$ and which not yet complete amount to II student $(36,7 \%)$. Speaking Skill evaluation at cognate domain and psikomotor obtained by mean 7I,I6. The mentioned indicate that the speaking skill is not yet reached the goals which have been determined.As for tables of result speaking skill the the following student in cycle I:

Tables 4. Complete result of Speaking Skill cycle I.

\begin{tabular}{|l|c|c|}
\hline \multicolumn{1}{|c|}{$\begin{array}{c}\text { SpeakingSkill } \\
\text { Results }\end{array}$} & Student & Percent \\
\hline Completed & I9 & $63,3 \%$ \\
\hline Not Completed & II & $36,7 \%$ \\
\hline Total & 30 & $100 \%$ \\
\hline
\end{tabular}


Based on the above table, the results of student's speaking skills have not met the expected target. Therefore there is a need for further action in cycle II. Researchers should correct the deficiencies found during the learning in cycle I so that the results of report speaking skills can be further improved. To get a visual overview of the student's speaking skill results on each indicator, it can be presented in the following diagram:

Figure 2: Bars Achievement Indicator Speaking Skills Cycle I

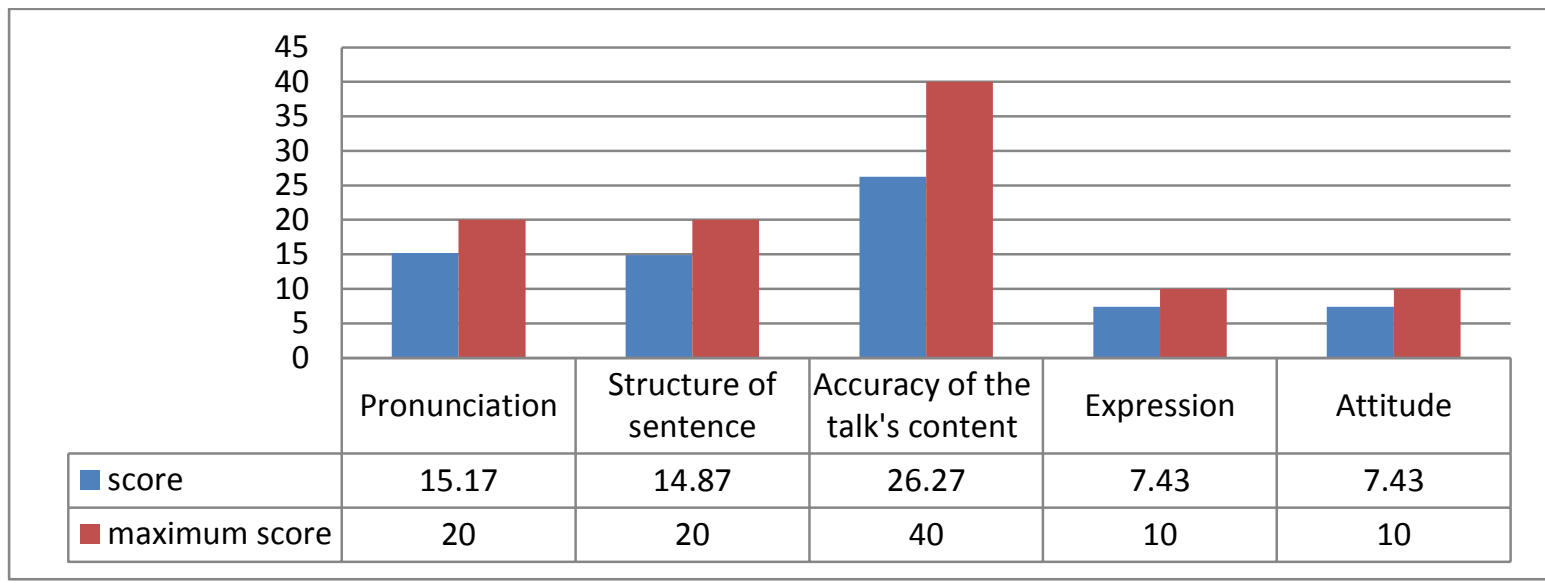

The results of the assessment of each indicator shows that the indicator of pronunciation reaches an average score of 15.17 from a maximum score of 20 , the sentence structure indicator achieves a score of 14.87 from a minimum score of 20 , the accuracy of speaking content reaches an average score of 26.27 from a maximum score of 40 , the expression indicator reaches an average score of 7.43 from a maximum score of 10 , and the attitude indicator achieves an average score of 7.43 from a maximum score of I0. The data indicates that there has been an increase when compared to the average score of each indicator in the pre cycle.

The Improved speaking skills were occurred because students carry out learning activities with a communicative approach. Teachers and students carry out learning speaking skills by involving the ability for learning objectives on the criteria assessed achieved, namely: pronunciation / pronunciation, sentence structure, accuracy of speaking content, expression and attitude.

\section{Cycle II}

Based on the evaluation of the theme of two "Events in Life" about "Various Events In Life". the result of the speaking skill is obtained from the test given at the end of cycle II in the form of test present and present the result of interview in the form of report. This is done to see the extent to which the increase in speaking skills and pour it in the form of writing through a communicative approach. The following results presented data processing student learning outcomes in the table below:

Tables 5. Distribution of Speaking Skill cycle II

\begin{tabular}{|c|c|c|c|}
\hline \multirow{2}{*}{$\begin{array}{c}\text { Interval } \\
\text { Score }\end{array}$} & \multicolumn{3}{|c|}{ Total of student } \\
\cline { 2 - 4 } & Frequency & $\begin{array}{c}\text { Relative } \\
(\%)\end{array}$ & Cumulative \\
\hline $70-74$ & II & 36.67 & 36.67 \\
\hline $75-79$ & I0 & 33.33 & 70.00 \\
\hline $80-84$ & 2 & 6.67 & 76.67 \\
\hline
\end{tabular}




\begin{tabular}{|l|c|c|c|}
\hline $85-89$ & 0 & 0 & 76.67 \\
\hline $90-94$ & 6 & 20.00 & 96.67 \\
\hline $95-99$ & I & 3.33 & 100.00 \\
\hline Total & 30 & 100 & \\
\hline
\end{tabular}

Based on the data in the table above, the result of speaking skill shows the most gain on the score 70-74 which is II students with $36.67 \%$ percentage. Based on the Minimum Criteria of Completeness (KKM) that has been established that is 70 , it is known that the complete all students with the number of 30 students (100\%). Evaluation of speaking skills was obtained with an average score of 79.00. It shows that students' speaking skills have reached the expected target. To get a visual overview of the students' speaking skill results on each indicator, it can be presented in the following diagram:

Figure 3: Bars Achievement Indicator Speaking Skills Cycle II

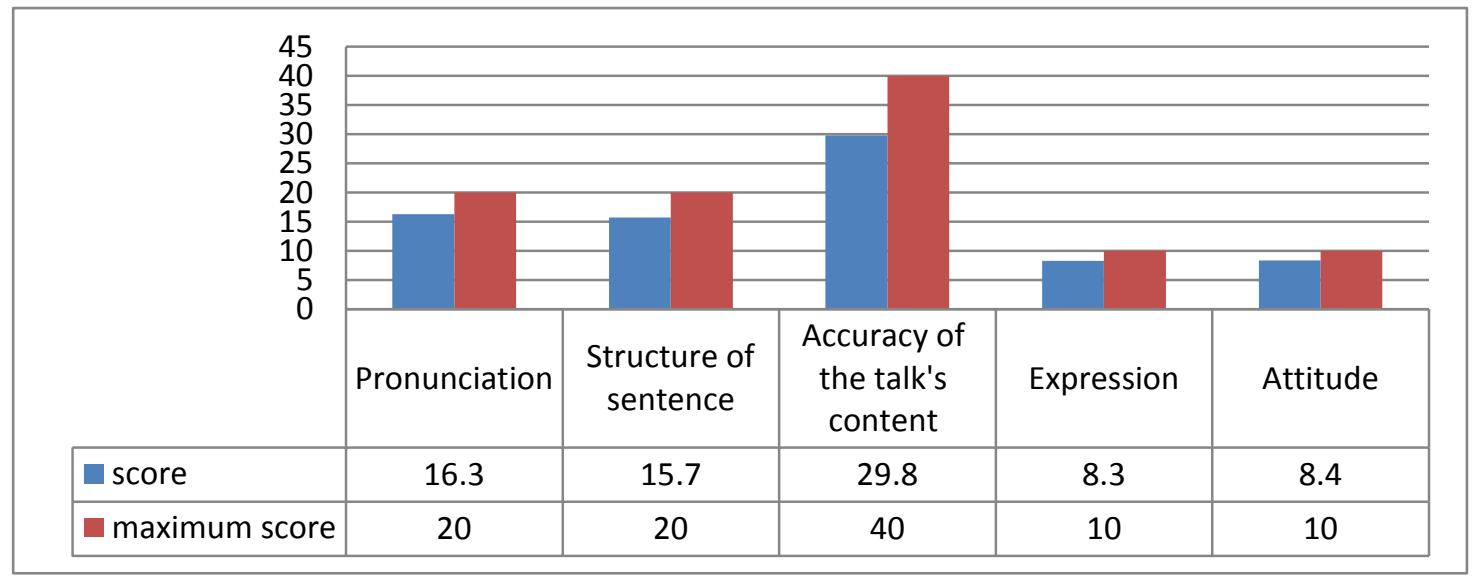

The result of the speaking skill in cycle II is the same as in cycle I, there are five indicators which are used as rubric of students' speaking skill, ie pronunciation / intonation, sentence structure, accuracy of speech content, expression and attitude.From the results of the assessment of speaking skill indicated that seven students $(23.33 \%)$ who got a score of between 85 - I00 (Criteria A), I2 students (40.00\%) scored between 75 - 84 (Criteria B), II students (36.67\%) got score between $60-74$ (Criteria C). Then the average student score is 79.00 .

The results of the assessment of each indicator shows that the indicator of pronunciation reaches an average score of 16.3 from a maximum score of 20, the sentence structure indicator reaches a score of I5.7 from a maximum score of 20, the accuracy of speaking content reaches an average score of 29.8 from a maximum score of 40 , the expression indicator achieves an average score of 8.3 from a maximum score of I0, and an attitude indicator achieves an average score of 8.4 from a maximum score of IO. The data indicates that there has been an increase when compared to the average score of each indicator in the pre cycle.

In the second cycle of complete students amounted to 30 students. The completeness table of students' writing skill in the second cycle is as follows:

Tables 6. Complete result of Speaking Skill cycle II.

\begin{tabular}{|l|c|c|}
\hline $\begin{array}{c}\text { SpeakingSkill } \\
\text { Results }\end{array}$ & Student & Percent \\
\hline Completed & 30 & $100 \%$ \\
\hline
\end{tabular}




\begin{tabular}{|l|c|c|}
\hline Not Completed & - & - \\
\hline Total & 30 & I00 \% \\
\hline
\end{tabular}

Pursuant to tables above skill of the student have fulfilled the expected goals, hence research of uplifting of skill converse through communicative approach at student of class V Padurenan II State Elementary School is discontinued at cycle II.

\section{Conclusion}

Conclusion of the research result, that is the improvement of speech skill through communicative approach to class $\mathrm{V}$ students with theme of "Objects in the Environment," subtema "Human and Environment". The results of students' speaking skills are significantly improved. This is evident with the students who are declared complete in cycle I, known as many as I9 students (63.3\%) and who have not completed as many as II students (36.7\%). Evaluation of listening skill in cycle I was obtained on average 7I,17. Improved speaking skills approaching the target and the value of the students there are only a few that are still below the minimum criterion of completeness criteria.

The result of speaking skills through a communicative approach to the second cycle of theme two 'Events in Life', subthemes of "Various Events in Life". It is known that thoroughly as many as 30 students $(100 \%)$. This indicates an increase in speaking skill in cycle II by obtaining an average of 78.60. In the second cycle of implementation of the action, the researcher has met the target that has been determined and expected, the research of improving speech skills through communicative approaches to grade V students of Padurenan II State Elementary School was stopped in cycle II. It proves that, communicative approach can improve the speaking skill of grade V students of Padurenan II State Elementary School, Mustikajaya Sub-district, Bekasi City.

\section{References}

Arsjad, Maidar G. \& Mukti U.S. I998.Development of Indonesian Speaking Capability. Jakarta: Erlangga

Asih. 2015. Learning Strategy of Indonesian Language, Bandung: Loyal Library.

Azie Furqanul \& Chaedar Alwasilah. 2002. Communicative Language Teaching. Bandung: Rosda

Eggen, Paul \& Don Kauchak. 2007. Educational Psychology. Usa: Pearson.

Ghazali, Gratitude. Language Learning Skills. Bandung, Aditama.

Hopkins, David. 20II. Teacher's Guide Research Class Action Research (A Teacher's Guide Classroom Research). Yogyakarta: Learning Library.

Hurlock, Elizabeth B. 2002. Developmental Psychology. Jakarta: Erlangga.

Madya, Suwarsih. 20II. Action Research - Action Research. Bandung: Alfabeta

Meleong, Lexy. 2005. Qualitative Research Methodology. Bandung: Youth Rosda Works.

Nurgiyantoro, Burhan. 20I4. Assessment of Language Learning. Yogyakarta: BpFE.

Nurjamal, Daeng. 20I4. Skillful Speaking. Bandung: Alfabeta.

Sukardi. 2005. Research Methodology of Competency Education and Practice. Jakarta: Earth Literacy.

Sumadayo, Samsu. 2013. Classroom Action Research. Yogyakarta: Graha Ilmu

Suyadi. 20I2. Teacher Guide Class Action Research Class (PTK) and School Action Research (PTS). Yogyakarta: Andi Publisher

Tarigan, Djago. 1996. Language Teaching Technique Skills. Bandung: Space.

Tanujaya, Benedict \& Jeinne Mumu. 2015. Classroom Action Research. Yogyakarta: Academy Media

Tarigan, Henry Thunder. 2015. Speaking As A Language Skill. Bandung: Space. 
Trianto, 20II.Classroom Action Research Guide Theory \& Practice. Jakarta: Achievements Pustaka Raya

Wassid, Iskandar \& Dadang Suhendar. 2016. Language Learning Strategy. Bandung, Rosda. Wiriatmadja, Rochiati. Classroom Action Research Methods. Bandung, Teens Rosdakarya.

Zulela, 2013. Learning Indonesian. Bandung: Remaja Rosda Karya. 